\title{
IMPLEMENTASI ALGORITMA GENETIKA DALAM PENJADWALAN KERJA DAN PENGAJUAN CUTI PEGAWAI DI PT.MEDAN SUGAR INDUSTRI
}

\author{
Yolanda Tua Parulian Simbolon', Asaziduhu Gea ${ }^{2}$ \\ Sistem Informasi, Fakultas Ilmu Komputer, Universitas Methodist Indonesia \\ 1'yolandasimbolon12@gmail.com, ${ }^{2}$ asaziduhugea@gmail.com
}

\begin{abstract}
The key to success in achieving the company's vision and mission is not only determined by the availability of technology and the availability of materials owned by the company. However, the potential of human resources is one of the capital that plays an important role in achieving company goals. However, the productivity of human resources can decrease due to various influencing factors. In addition to individual factors that come from the employees themselves, excessive workload is a factor that can cause a decrease in employee productivity. Therefore, employees need to get good treatment in terms of the division of working hours, so that employees can work more optimally. The division of work shifts is one solution that can be carried out by the company. The problem with the existing leave application system at PT. Medan Sugar Industry is still done manually. Checking the remaining leave, submitting leave, and leaving approval is carried out in stages and still relies on the leave card contained in each employee file data. With the Scheduling and Submission System for employee leave using the Genetic Algorithm Method at PT. Medan Sugar Industry, the employee scheduling process can be computerized and more effective.
\end{abstract}

Keywords: Scheduling, Leave Application, Genetic Algorithm.

\section{PENDAHULUAN}

Kunci Sukses keberhasilan pencapaian visi misi perusahaan tidak hanya di tentukan oleh ketersediaan teknologi serta ketersediaan material yang dimiliki oleh perusahaan. Akan tetapi potensi sumber daya manusia merupakan salah satu modal yang memegang peranan pentinguntuk pencapaian tujuan perusahaan. Kebutuhan sumber daya manusia dengan kompetensi tinggi menjadi faktor yang menentukan persaingan usaha. Namun produktivitas sumber daya manusia bisa menurun karena berbagai macam faktor yang mempengaruhi. Selain faktor individual yang berasal dari diri karyawan itu sendiri, faktor beban pekerjaan yang berlebihan menjadi faktor yang dapat menimbulkan penurunan produktivitas karyawan. Oleh karena itu karyawan perlu mendapatkan perlakuan yang baik dari sisi pembagian jam kerja, sehingga karyawan bisa bekerja lebih optimal. Pembagian shift kerja merupakan salah-satu solusi yang bisa dijalankan oleh perusahaan. Seperti yang selama ini dijalankan oleh PT.Medan Sugar Industri namun masih belum optimal, misalnya masih terdapat shift yang double atau ketidakteraturan pembagian shift.

\section{LANDASAN TEORI}

\section{Sistem Informasi}

Sistem Informasi merupakan suatu sistem di dalam suatu organisasi yang mempertemukan kebutuhan pengolahan transaksi harian, mendukung operasi,bersifat manajerial dan kegiatan strategi dari suatu organisasi dan menyediakan pihak luar tertentu dengan laporan-laporan yang diperlukan (Arista Mahaseptiviana, 2014)

\section{Algoritma Genetika}

Algoritma genetika adalah suatu algoritma pencarian yang berbasis pada mekanisme seleksi alam dan genetika. Algoritma genetika merupakan salah satu algoritma yang sangat tepat digunakan dalam menyelesaikan masalah optimasi kompleks, yang sulit dilakukan oleh metode konvernsional.

\section{Penjadwalan dan Pengajuan Cuti}

Penjadwalan adalah aktivitas perencanaan untuk menentukan kapan dan dimana setiap operasi sebagai bagian dari pekerjaan secara keseluruhan harus dilakukan pada sumber daya yang terbatas, serta pengalokasian sumber daya pada suatu waktu tertentu dengan memperhatikan kapasitas sumber daya yang ada(Nunung Indra Lesmana, 2016). Cuti secara umum dapat diartikan tidak masuk kerja yang diizinkan dalam jangka waktu tertentu dan mematuhi semua peraturan yang berlaku di perusahaan tersebut. Jenis cuti merupakan macam-macam cuti yang dapat diajukan oleh karyawan di PT. Medan Sugar Industri.

\section{Database}

Database adalah kumpulan dari item data yang saling berhubungan satu dengan yang lainnya yang diorganisasikan berdasarkan sebuah skema atau struktur tertentu, yang kelak dapat dimanfaatkan kembali dengan cepat dan mudah. Database juga merupakan kumpulan data (elementer) yang secara logic berkaitan dalam mempresentasikan fenomena/fakta secara terstruktur dalam domain tertentu untuk mendukung aplikasi dalam system tertentu (Minarni, 2014) 


\section{IV.ANALISA DAN PERANCANGAN SISTEM}

Menentukan Penjadwalan Kerja Dengan Menggunakan Algoritma Genetika dengan nilai Crossover Probabiliy $=25 \%$, Kromosom $=3$, Mutasi $=40 \%$, dan proses iterasi sebanyak $1 \mathrm{x}$

\section{Data Karyawan}

Data karyawan berisikan pengkodean setiap karyawan seperti Tabel 1:

\begin{tabular}{|l|l|}
\hline Kode Karyawan & Nama Karyawan \\
\hline K1 & Andi \\
\hline K2 & Johan \\
\hline K3 & Budi \\
\hline K4 & Robi \\
\hline K5 & Kiki \\
\hline
\end{tabular}

\section{Data Shift}

Data shift berisikan pengkodean shift kerja yang dapat dilihat pada tabel 2 :

\begin{tabular}{|l|l|}
\hline Kode Shift & Shifi \\
\hline SP & Pagi \\
\hline SS & Siang \\
\hline SM & Malam \\
\hline L & Libur \\
\hline
\end{tabular}

\section{Menentukan Populasi Awal dan Inisialisasi Kromosom}

Menenetukan populasi awal dengan cara membangkitkan sejumlah kromosom dengan teknik random pada representasi gen. dalam satu kromosom memiliki gabungan dari gen berdasarkan kode gan itu sendiri seperti kode hari, kode shift, dan kode karyawan. Seperti contoh dibawah ini inisialisasi pembentukan kromosom data hari pada tabel 1, data shift pada tabel 2 dan data karyawan pada tabel 4 berikut :

\begin{tabular}{|l|l|l|l|l|l|l|l|}
\hline & $\begin{array}{l}\text { Sen } \\
\text { in }\end{array}$ & $\begin{array}{l}\text { Sel } \\
\text { asa }\end{array}$ & $\begin{array}{l}\text { Rab } \\
\text { u }\end{array}$ & $\begin{array}{l}\text { Ka } \\
\text { mis }\end{array}$ & $\begin{array}{l}\text { Jum } \\
\text { at }\end{array}$ & $\begin{array}{l}\text { Sab } \\
\text { tu }\end{array}$ & $\begin{array}{l}\text { Min } \\
\text { ggu }\end{array}$ \\
\hline Kromo & K1 & K1 & K1 & K1 & K1 & K1 & K1S \\
som 1 & SP & SP & L & SP & SP & SP & P \\
& K2 & K2 & K2 & K2 & K2 & K2 & K2S \\
& SP & SS & SM & SP & L & SS & M \\
& K3 & K3 & K3 & K3 & K3 & K3 & K3S \\
& SP & SP & SM & SS & L & SP & P \\
& K4 & K4 & K4 & K4 & K4 & K4 & K4L \\
& SP & SM & SS & L & L & SM & K5S \\
& K5 & K5 & K5 & K5 & K5 & K5 & P \\
& SP & SM & SP & SP & SP & L & \\
\hline Kromo & K1 & K1 & K1 & K1 & K1 & K1 & K1S \\
som 2 & SP & L & L & SP & SP & SP & P \\
& K2 & K2 & K2 & K2 & K2 & K2 & K2S \\
& SP & SM & L & SS & SP & L & S \\
& K3 & K3 & K3 & K3 & K3 & K3 & K3S \\
& SS & L & SP & SM & SS & SP & M \\
& K4 & K4 & K4 & K4 & K4 & K4 & K4S \\
& L & SS & SM & SM & L & SS & M \\
& K5 & K5 & K5 & K5 & K5 & K5 & K5S \\
& SM & L & SS & SS & SM & SM & M \\
& & & & & & & \\
\hline Kromo & K1 & K1 & K1 & K1 & K1 & K1 & K1S \\
som 3 & L & L & L & L & SM & SM & M \\
\hline
\end{tabular}

\begin{tabular}{|l|l|l|l|l|l|l|l|}
\hline & K2 & K2 & K2 & K2 & K2 & K2 & K2S \\
L & SS & SP & SM & SM & SS & M \\
K3 & K3 & K3 & K3 & K3 & K3 & K3L \\
& L & L & SP & SM & L & SM & K4L \\
K4 & K4 & K4 & K4 & K4 & K4 & K5L \\
SP & SM & SM & SS & L & L & \\
K5 & K5 & K5 & K5 & K5 & K5 & \\
SP & SM & SM & SS & L & L & \\
\hline
\end{tabular}

\section{Menghitung Nilai Fitness}

Menghitung nilai fitness berfungsi untuk mengukur masing-masing kualitas kromosom dan menandakan seberapa optimal solusi yang diperoleh. Hasil dari nilai fitness akan digunakan pada proses selanjutnya pada tahapan seleksi untuk mencari kromosom terbaik yang akan menjadi solusi terbaik dalam penyelesaian masalah. Pada peneltian ini menghitung nilai fitness digunakan rumus :

$$
\text { fitness }=\frac{1}{1+\left(\sum P\right)}
$$

Keterangan :

P1 = Nilai pelanggaran terhadap Hard Constraint karyawan tidak boleh jaga shift yang sama ke esokan harinya.

Dalam penelitian ini P1 dan P2 merupakan pelanggaran yang tidak sesuai dengan aturan yang memiliki nilai pelanggaran kemunculan pada kromosom dengan setiap kemunculan memiliki nilai yang berbeda-beda sesuai dengan jenis pelanggaran tersebut seperti Tabel 5 :

\begin{tabular}{|l|l|l|l|}
\hline $\begin{array}{l}\text { Kode } \\
\text { Pelanggaran }\end{array}$ & Keterangan & $\begin{array}{l}\text { Jenis } \\
\text { Pelanggaran }\end{array}$ & $\begin{array}{l}\text { Nilai } \\
\text { Pelanggaran }\end{array}$ \\
\hline $\mathrm{P}$ & $\begin{array}{l}\text { Karyawan } \\
\text { Tidak } \\
\text { Boleh Jaga } \\
\text { Shift yang } \\
\text { sama } \\
\text { keesokan } \\
\text { harinya }\end{array}$ & $\begin{array}{l}\text { Constraint } \\
\text { ama }\end{array}$ & 0.2 \\
\hline
\end{tabular}

Proses pelanggaran dapat dilihat pada tabel populasi pada setiap kromosom seperti yang terlihat pada tabel di bawah ini

\begin{tabular}{|l|l|l|l|l|l|l|l|}
\hline & $\begin{array}{l}\text { Sen } \\
\text { in }\end{array}$ & $\begin{array}{l}\text { Sel } \\
\text { asa }\end{array}$ & $\begin{array}{l}\text { Rab } \\
\text { u }\end{array}$ & $\begin{array}{l}\text { Ka } \\
\text { mis }\end{array}$ & $\begin{array}{l}\text { Jum } \\
\text { at }\end{array}$ & $\begin{array}{l}\text { Sab } \\
\text { tu }\end{array}$ & $\begin{array}{l}\text { Min } \\
\text { ggu }\end{array}$ \\
\hline Kromo & K1 & K1 & K1 & K1 & K1 & K1 & K1S \\
som 1 & SP & SP & L & SP & SP & SP & P \\
& K2 & K2 & K2 & K2 & K2 & K2 & K2S \\
& SP & SS & SM & SP & L & SS & M \\
& K3 & K3 & K3 & K3 & K3 & K3 & K3S \\
& SP & SP & SM & SS & L & SP & P \\
& K4 & K4 & K4 & K4 & K4 & K4 & K4L \\
& SP & SM & SS & L & L & SM & K5S \\
& K5 & K5 & K5 & K5 & K5 & K5 & P \\
& SP & SM & SP & SP & SP & L & \\
\hline Kromo & K1 & K1 & K1 & K1 & K1 & K1 & K1S \\
som 2 & SP & L & L & SP & SP & SP & P \\
& K2 & K2 & K2 & K2 & K2 & K2 & K2S \\
& SP & SM & L & SS & SP & L & S \\
\hline
\end{tabular}




\begin{tabular}{|l|l|l|l|l|l|l|l|}
\hline & K3 & K3 & K3 & K3 & K3 & K3 & K3S \\
SS & L & SP & SM & SS & SP & M \\
& K4 & K4 & K4 & K4 & K4 & K4 & K4S \\
& L & SS & SM & SM & L & SS & M \\
& K5 & K5 & K5 & K5 & K5 & K5 & K5S \\
& SM & L & SS & SS & SM & SM & M \\
\hline Kromo & K1 & K1 & K1 & K1 & K1 & K1 & K1S \\
som 3 & L & L & L & L & SM & SM & M \\
& K2 & K2 & K2 & K2 & K2 & K2 & K2S \\
& L & SS & SP & SM & SM & SS & M \\
& K3 & K3 & K3 & K3 & K3 & K3 & K3L \\
& L & L & SP & SM & L & SM & K4L \\
& K4 & K4 & K4 & K4 & K4 & K4 & K5L \\
& SP & SM & SM & SS & L & L & \\
& K5 & K5 & K5 & K5 & K5 & K5 & \\
& SP & SM & SM & SS & L & L & \\
\hline
\end{tabular}

Dari tabel di atas dapat dilihat pelanggaran yaitu setiap karyawan tidak boleh memiliki shift yang sama untuk hari berikutnya yaitu: dimana kromosom 1 memiliki 9 pelanggaran, kromosom 2 memiliki 8 pelanggaran dan kromosom 3 memiliki 13 pelanggaran sehingga nilai fitness dapat dicari seperti di bawah ini

$\mathrm{P} 1=\frac{1}{1+(0.2 * 9)}=0.3571$

$\mathrm{P} 2=\frac{1}{1+(0.2 * 8)}=0.3846$

$\mathrm{P} 3=\frac{1}{1+(0.2 * 13)}=0.278$

Rumus untuk mencari probabilitas: $\mathrm{P}[\mathrm{i}]=$ fitness $[\mathrm{i}] /$ total_fitness

$\mathrm{P} 1=0.3571 / 1.0197=0.3502$

$\mathrm{P} 2=0.3846 / 1.0197=0.3771$

$\mathrm{P} 3=0.278 / 1.0197=0.2726$

Dari probabilitas diatas dapat kita lihat kalau chromosome ke 2 yang mempunyai fitness paling besar maka chromosome tersebut mempunyai probabilitas untuk terpilih pada generasi selanjutnya lebih besar dari chromosome lainnya. Untuk proses seleksi kita gunakan roulete wheel, untuk itu kita harus mencari dahulu nilai kumulatif probabilitasnya:

$\mathrm{C}[1]=0.3502$

$C[2]=0.3771+0.3502=0.7273$

$\mathrm{P} 3=0.3771+0.3502+0.7273=1$

Setelah dihitung cumulative probabilitasnya maka proses seleksi menggunakan roulete-wheel dapat dilakukan. Prosesnya adalah dengan membangkitkan bilangan acak $\mathrm{R}$ dalam range $0-1$. Jika $\mathrm{R}[\mathrm{k}]<\mathrm{C}[1]$ maka pilih chromosome 1 sebagai induk, selain itu pilih chromosome ke-k sebagai induk dengan syarat $\mathrm{C}[\mathrm{k}-1]<$ $\mathrm{R}<\mathrm{C}[\mathrm{k}]$. Kita putar roulete wheel sebanyak jumlah populasi yaitu 3 kali (bangkitkan bilangan acak R) dan pada tiap putaran, kita pilih satu chromosome untuk populasi baru. Misal: $R[1]=0.458 R[2]=0.284 R[3]=$ 0.514
Angka acak pertama R[1] adalah lebih besar dari C[1] dan lebih kecil daripada $\mathrm{C}[2]$ maka pilih chromosome[2] sebagai chromosome pada populasi baru, dari bilangan acak yang telah dibangkitkan diatas maka populasi chromosome baru hasil proses seleksi adalah:

$$
\begin{aligned}
& \text { chromosome[1] = chromosome[2] } \\
& \text { chromosome[2] }=\text { chromosome[1] } \\
& \text { chromosome[3] = chromosome[2] }
\end{aligned}
$$

Chromosome baru hasil proses seleksi:

\begin{tabular}{|l|l|l|l|l|l|l|l|}
\hline & $\begin{array}{l}\text { Sen } \\
\text { in }\end{array}$ & $\begin{array}{l}\text { Sel } \\
\text { asa }\end{array}$ & $\begin{array}{l}\text { Rab } \\
\text { u }\end{array}$ & $\begin{array}{l}\text { Ka } \\
\text { mis }\end{array}$ & $\begin{array}{l}\text { Jum } \\
\text { at }\end{array}$ & $\begin{array}{l}\text { Sab } \\
\text { tu }\end{array}$ & $\begin{array}{l}\text { Min } \\
\text { ggu }\end{array}$ \\
\hline Kromo & K1 & K1 & K1 & K1 & K1 & K1 & K1S \\
SP & L & L & SP & SP & SP & P \\
& K2 & K2 & K2 & K2 & K2 & K2 & K2S \\
& SP & SM & L & SS & SP & L & S \\
& K3 & K3 & K3 & K3 & K3 & K3 & K3S \\
& SS & L & SP & SM & SS & SP & M \\
& K4 & K4 & K4 & K4 & K4 & K4 & K4S \\
& L & SS & SM & SM & L & SS & M \\
& K5 & K5 & K5 & K5 & K5 & K5 & K5S \\
& SM & L & SS & SS & SM & SM & M \\
& & & & & & & \\
\hline Kromo & K1 & K1 & K1 & K1 & K1 & K1 & K1S \\
SP & SP & L & SP & SP & SP & P \\
& K2 & K2 & K2 & K2 & K2 & K2 & K2S \\
& SP & SS & SM & SP & L & SS & M \\
& K3 & K3 & K3 & K3 & K3 & K3 & K3S \\
& SP & SP & SM & SS & L & SP & P \\
& K4 & K4 & K4 & K4 & K4 & K4 & K4L \\
& SP & SM & SS & L & L & SM & K5S \\
& K5 & K5 & K5 & K5 & K5 & K5 & P \\
& SP & SM & SP & SP & SP & L & \\
\hline K1 & K1 & K1 & K1 & K1 & K1 & K1S \\
Kromo & SP & L & L & SP & SP & SP & P \\
& K2 & K2 & K2 & K2 & K2 & K2 & K2S \\
& SP & SM & L & SS & SP & L & S \\
& K3 & K3 & K3 & K3 & K3 & K3 & K3S \\
& SS & L & SP & SM & SS & SP & M \\
& K4 & K4 & K4 & K4 & K4 & K4 & K4S \\
& L & SS & SM & SM & L & SS & M \\
& K5 & K5 & K5 & K5 & K5 & K5 & K5S \\
& SM & L & SS & SS & SM & SM & M \\
& & & & & & \\
\hline
\end{tabular}

\section{Crossover}

Setelah proses seleksi maka proses selanjutnya adalah proses crossover. Metode yang digunakan salah satunya adalah one-cut point, yaitu memilih secara acak satu posisi dalam chromosome induk kemudian saling menukar gen. Chromosome yang dijadikan induk dipilih secara acak dan jumlah chromosome yang mengalami crossover dipengaruhi oleh parameter crossover_rate $(\rho c)$. Misal ditentukan crossover probability adalah sebesar $25 \%$, maka diharapkan dalam satu generasi ada 50\% Chromosome (3 chromosome) dari satu generasi mengalami proses crossover. Prosesnya adalah sebagai berikut: Pertama kita bangkitkan bilangan acak R sebanyak jumlah populasi $\mathrm{R}[1]=0.191$

$\mathrm{R}[2]=0.259$

$\mathrm{R}[3]=0.760$ 
Maka Chromosome ke k akan dipilih sebagai induk jika $\mathrm{R}[\mathrm{k}]<\rho \mathrm{c}$, dari bilangan acak $\mathrm{R}$ diatas maka yang dijadikan induk adalah chromosome[1] dan chromosome[2]. Setelah melakukan pemilihan induk proses selanjutnya adalah menentukan posisi crossover. Ini dilakukan dengan cara membangkitkan bilangan acak dengan batasan 1 sampai (panjang chromosome-1), dalam kasus ini bilangan acak yang dibangkitkan adalah 1 - 2. Misalkan didapatkan posisi crossover adalah 1 maka chromosome induk akan dipotong mulai gen ke 1 kemudian potongan gen tersebut saling ditukarkan antar induk.

chromosome[1] $><$ chromosome[2]

chromosome[2] $><$ chromosome[1]

Posisi cut-point crossover dipilih menggunakan bilangan acak 1-7 sebanyak jumlah crossover yang terjadi, misal

$\mathrm{C}[1]=1$

$\mathrm{C}[2]=2$

offspring $[1]=$ chromosome $[1]\rangle\langle$ chromosome[2]

\begin{tabular}{|l|l|l|l|l|l|l|l|}
\hline & $\begin{array}{l}\text { Sen } \\
\text { in }\end{array}$ & $\begin{array}{l}\text { Sel } \\
\text { asa }\end{array}$ & $\begin{array}{l}\text { Rab } \\
\text { u }\end{array}$ & $\begin{array}{l}\text { Ka } \\
\text { mis }\end{array}$ & $\begin{array}{l}\text { Ju } \\
\text { mat }\end{array}$ & $\begin{array}{l}\text { Sab } \\
\text { tu }\end{array}$ & $\begin{array}{l}\text { Min } \\
\text { ggu }\end{array}$ \\
\hline offspri & K1 & K1 & K1 & K1 & K1 & K1 & K1S \\
ng[1] & SP & SP & L & SP & SP & SP & P \\
& K2 & K2 & K2 & K2 & K2 & K2 & K2S \\
& SP & SS & SM & SP & L & SS & M \\
& K3 & K3 & K3 & K3 & K3 & K3 & K3S \\
& SS & SP & SM & SS & L & SP & P \\
& K4 & K4 & K4 & K4 & K4 & K4 & K4L \\
& L & SM & SS & L & L & SM & K5S \\
& K5 & K5 & K5 & K5 & K5 & K5 & P \\
& SM & SM & SP & SP & SP & L & \\
\hline
\end{tabular}

offspring [2] $=$ chromosome $[2]><$ chromosome[1]

\begin{tabular}{|l|l|l|l|l|l|l|l|}
\hline & $\begin{array}{l}\text { Sen } \\
\text { in }\end{array}$ & $\begin{array}{l}\text { Sela } \\
\text { sa }\end{array}$ & $\begin{array}{l}\text { Rab } \\
\text { u }\end{array}$ & $\begin{array}{l}\text { Ka } \\
\text { mis }\end{array}$ & $\begin{array}{l}\text { Ju } \\
\text { mat }\end{array}$ & $\begin{array}{l}\text { Sab } \\
\text { tu }\end{array}$ & $\begin{array}{l}\text { Min } \\
\text { ggu }\end{array}$ \\
\hline offspri & K1 & K1 & K1 & K1 & K1 & K1 & K1S \\
ng[2] & SP & SP & L & SP & SP & SP & P \\
& K2 & K2 & K2 & K2 & K2 & K2 & K2S \\
& SP & SS & SM & SP & L & SS & M \\
& K3 & K3 & K3 & K3 & K3 & K3 & K3S \\
& SP & SP & SM & SS & L & SP & P \\
& K4 & K4 & K4 & K4 & K4 & K4 & K4L \\
& SP & SM & SS & L & L & SM & K5S \\
& K5 & K5 & K5 & K5 & K5 & K5 & P \\
& SP & SM & SP & SP & SP & L & \\
\hline
\end{tabular}

Dengan demikian populasi Chromosome setelah mengalami proses crossover menjadi:

\begin{tabular}{|l|l|l|l|l|l|l|l|}
\hline & $\begin{array}{l}\text { Sen } \\
\text { in }\end{array}$ & $\begin{array}{l}\text { Sel } \\
\text { asa }\end{array}$ & $\begin{array}{l}\text { Rab } \\
\text { u }\end{array}$ & $\begin{array}{l}\text { Ka } \\
\text { mis }\end{array}$ & $\begin{array}{l}\text { Jum } \\
\text { at }\end{array}$ & $\begin{array}{l}\text { Sab } \\
\text { tu }\end{array}$ & $\begin{array}{l}\text { Min } \\
\text { ggu }\end{array}$ \\
\hline Kromo & K1 & K1 & K1 & K1 & K1 & K1 & K1S \\
som 1 & SP & SP & L & SP & SP & SP & P \\
& K2 & K2 & K2 & K2 & K2 & K2 & K2S \\
& SP & SS & SM & SP & L & SS & M \\
& K3 & K3 & K3 & K3 & K3 & K3 & K3S \\
& SS & SP & SM & SS & L & SP & $\begin{array}{l}\text { P } \\
\text { K4L }\end{array}$ \\
\hline
\end{tabular}

\begin{tabular}{|l|l|l|l|l|l|l|l|}
\hline & K4 & K4 & K4 & K4 & K4 & K4 & K5S \\
& L & SM & SS & L & L & SM & P \\
& K5 & K5 & K5 & K5 & K5 & K5 & \\
& SM & SM & SP & SP & SP & L & \\
\hline Kromo & K1 & K1 & K1 & K1 & K1 & K1 & K1S \\
som 2 & SP & SP & L & SP & SP & SP & P \\
& K2 & K2 & K2 & K2 & K2 & K2 & K2S \\
& SP & SS & SM & SP & L & SS & M \\
& K3 & K3 & K3 & K3 & K3 & K3 & K3S \\
& SP & SP & SM & SS & L & SP & P \\
& K4 & K4 & K4 & K4 & K4 & K4 & K4L \\
& SP & SM & SS & L & L & SM & K5S \\
& K5 & K5 & K5 & K5 & K5 & K5 & P \\
& SP & SM & SP & SP & SP & L & \\
\hline Kromo & K1 & K1 & K1 & K1 & K1 & K1 & K1S \\
som 3 & L & L & L & L & SM & SM & M \\
& K2 & K2 & K2 & K2 & K2 & K2 & K2S \\
& L & SS & SP & SM & SM & SS & M \\
& K3 & K3 & K3 & K3 & K3 & K3 & K3L \\
& L & L & SP & SM & L & SM & K4L \\
& K4 & K4 & K4 & K4 & K4 & K4 & K5L \\
& SP & SM & SM & SS & L & L & \\
& K5 & K5 & K5 & K5 & K5 & K5 & \\
& SP & SM & SM & SS & L & L & \\
\hline
\end{tabular}

\section{Mutasi}

Jumlah chromosome yang mengalami mutasi dalam satu populasi ditentukan oleh parameter mutation_rate. Proses mutasi dilakukan dengan cara mengganti satu gen yang terpilih secara acak dengan suatu nilai baru yang didapat secara acak. Prosesnya adalah sebagai berikut. Pertama kita hitung dahulu panjang total gen yang ada dalam satu populasi. Dalam kasus ini panjang total gen adalah:

total_gen $=($ jumlah gen dalam chromosome $) *$ jumlah populasi $=35 * 3=105$

Untuk memilih posisi gen yang mengalami mutasi dilakukan dengan cara membangkitkan bilangan integer acak antara 1 sampai total_gen, yaitu 1 sampai 105. Jika bilangan acak yang kita bangkitkan lebih kecil daripada variabel mutation_rate $(\rho \mathrm{m})$ maka pilih posisi tersebut sebagai sub-chromosome yang mengalami mutasi. Misal $\rho$ m kita tentukan $40 \%$ maka diharapkan ada $40 \%$ dari total_gen yang mengalami populasi: jumlah mutasi $=0.4 * 105=42$

Misalkan setelah kita bangkitkan bilangan acak terpilih posisi

gen

$1,2,5,7,10,11,15,18,19,20,21,23,24,25,30,35,39,40,41,4$ $3,46,47,51,52,55,57,60,61,65,68,69,70,71,73,74,75,80$, $85,89,90$ yang mengalami mutasi. D Maka nilai gen pada posisi tersebut kita ganti dengan bilangan acak seperti yang ditampilkan pada gambar di bawah ini :

\begin{tabular}{|l|l|l|l|l|l|l|l|}
\hline & $\begin{array}{l}\text { Sen } \\
\text { in }\end{array}$ & $\begin{array}{l}\text { Sel } \\
\text { asa }\end{array}$ & $\begin{array}{l}\text { Rab } \\
\text { u }\end{array}$ & $\begin{array}{l}\text { Ka } \\
\text { mis }\end{array}$ & $\begin{array}{l}\text { Jum } \\
\text { at }\end{array}$ & $\begin{array}{l}\text { Sab } \\
\text { tu }\end{array}$ & $\begin{array}{l}\text { Min } \\
\text { ggu }\end{array}$ \\
\hline Kromo & K1 & K1 & K1 & K1 & K1 & K1 & K1S \\
som 1 & SM & SS & L & SP & SM & SP & M \\
& K2 & K2 & K2 & K2 & K2 & K2 & K2S \\
& SP & SS & SP & SM & L & SS & M \\
& K3 & K3 & K3 & K3 & K3 & K3 & K3S \\
SM & SP & L & SP & L & SM & S \\
& K4 & K4 & K4 & K4 & K4 & K4 & K4L \\
L & SP & SM & SS & L & SM & \\
\hline
\end{tabular}




\begin{tabular}{|l|l|l|l|l|l|l|l|}
\hline & K5 & K5 & K5 & K5 & K5 & K5 & K5S \\
& SM & SS & SP & SP & SP & L & M \\
\hline Kromo & K1 & K1 & K1 & K1 & K1 & K1 & K1S \\
som 2 & SP & SP & L & SM & SS & L & P \\
& K2 & K2 & K2 & K2 & K2 & K2 & K2S \\
& SM & SS & SM & L & SM & SS & M \\
& K3 & K3 & K3 & K3 & K3 & K3 & K3S \\
& SP & SS & SP & SS & L & SM & P \\
& K4 & K4 & K4 & K4 & K4 & K4 & K4L \\
& SS & SM & SS & SM & SS & SM & K5L \\
& K5 & K5 & K5 & K5 & K5 & K5 & \\
& SP & SS & SP & SP & SS & SM & \\
\hline Kromo & K1 & K1 & K1 & K1 & K1 & K1 & K1S \\
som 3 & SS & L & SM & SS & SP & SM & M \\
& K2 & K2 & K2 & K2 & K2 & K2 & K2S \\
& L & SS & SS & SM & SM & SS & M \\
& K3 & K3 & K3 & K3 & K3 & K3 & K3L \\
& SS & L & SP & SM & SS & SP & K4L \\
& K4 & K4 & K4 & K4 & K4 & K4 & K5L \\
& SP & SM & SM & SS & L & L & \\
& K5 & K5 & K5 & K5 & K5 & K5 & \\
& SP & SM & SM & SS & L & L & \\
\hline
\end{tabular}

Dari tabel di atas dapat dilihat pelanggaran yaitu setiap karyawan tidak boleh memiliki shift yang sama untuk hari berikutnya yaitu: dimana kromosom 1 memiliki 2 pelanggaran, kromosom 2 memiliki 2 pelanggaran dan kromosom 3 memiliki 9 pelanggaran sehingga nilai fitness dapat dicari seperti di bawah ini:

$\mathrm{P} 1=\frac{1}{1+(0.2 * 2)}=0.7142$

$\mathrm{P} 2=\frac{1}{1+(0.2 * 2)}=0.7142$

$\mathrm{P} 3=\frac{1}{1+(0.2 * 8)}=0.384$

Nilai Fitness dari ketiga kromosom memiliki peningkatan dari nilai kromosom populasi awal dan ini membuktikan bahwa algoritma genetika dapat meminimalkan proses pelanggaran. Dari ketiga kromosom tersebut nilai terbesar dimiliki oleh kromosom 1 dan 2 tetapi masih ditemukan pelanggaran, untuk mengatasi hal tersebut proses iterasi harus dilakukan kembali. Proses iterasi harus dilakukan sebanyak mungkin sampai tidak ditemukan pelanggaran dan proses ini akan dilakukan secara komputasi pada sistem yang akan dibangun dikarenakan proses iterasi harus dilakukan sebanyak-banyaknya agar mendapatkan hasil optimal dan apabila dilakukan secara manual akan tidak terasa efektif dan memerlukan waktu yang lama.

\section{PEMBAHASAN}

Implementasi Sistem adalah langkah-langkah atau prosedur yang dilakukan dalam menyelesaikan desain sistem yang telah disetujui, menguji, dan memulai sistem baru yang telah disempurnakan

\section{Perancangan Login HRD}

Perancangan login berfungsi bagi HRD menginput data username dan password sebelum masuk ke halaman akun HRD. Perancangan login HRD dapat dilihat pada gambar di bawah ini

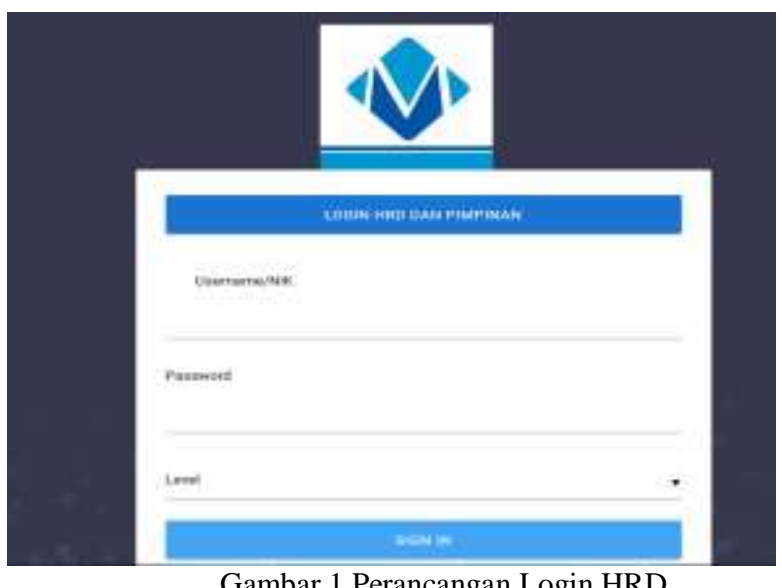

\section{Perancangan Input Data User}

Perancangan input data User berfungsi bagi HRD menginput data User yang baru. Data yang diinput adalah username,email, password, dan konfirmasi password

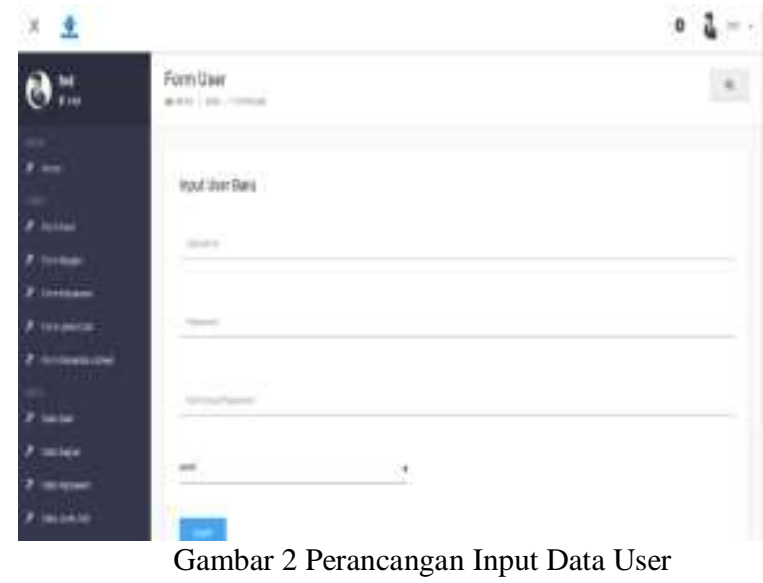

\section{Perancangan Input Data Bagian}

Perancangan input data Bagian berfungsi bagi HRD menginput data Bagian yang baru. Data yang diinput adalah nama Bagian

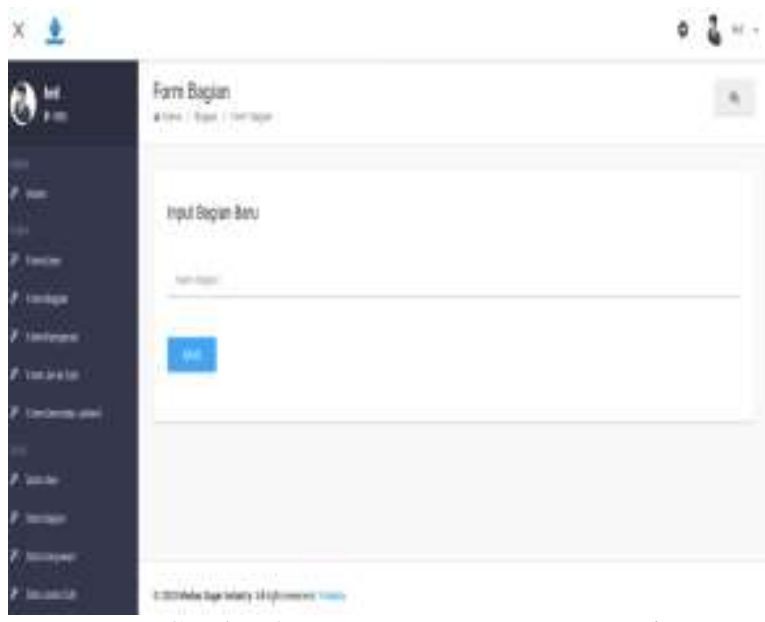

Gambar 3 Perancangan Input Data Bagian 


\section{Perancangan Input Data Karyawan}

Perancangan input data Karyawan berfungsi bagi HRD menginput data Karyawan yang baru. Data yang diinput adalah NIK,nama karyawan, bagian, password,alamat, nomor HP, dan tahun mulai bekerja.

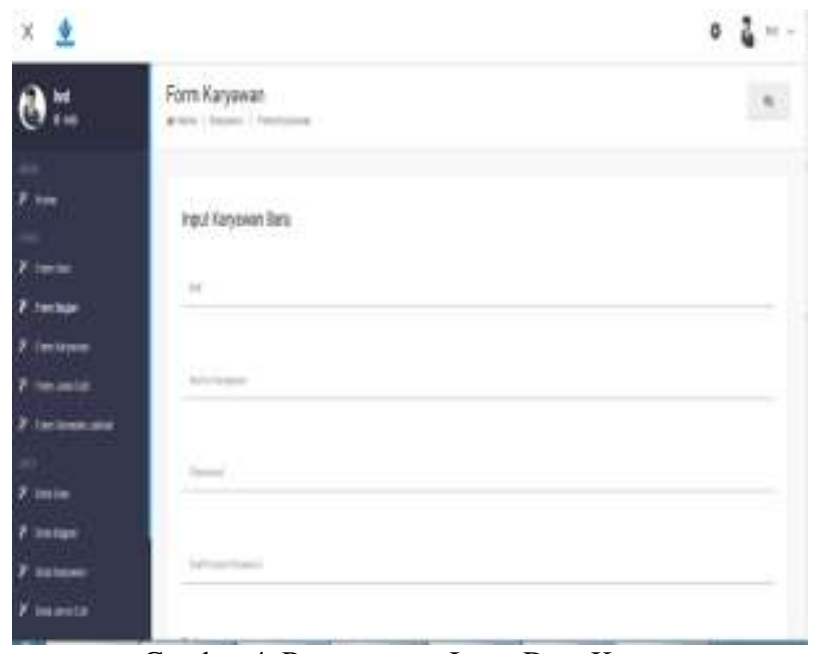

Gambar 4. Perancangan Input Data Karyawan

\section{Perancangan Input Data Jenis Cuti}

Perancangan input data Karyawan berfungsi bagi HRD menginput data jenis cuti yang baru. Data yang diinput adalah nama jenis cuti dan deskripsi

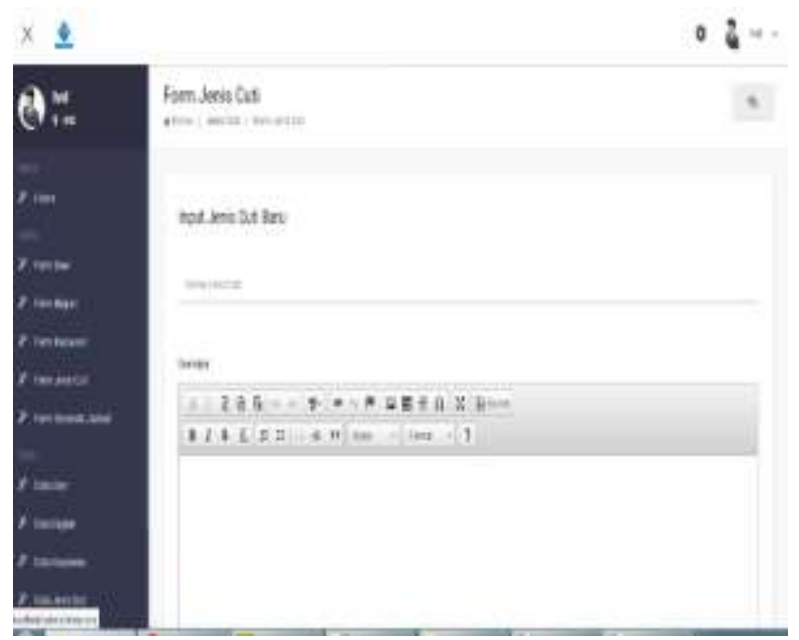

Gambar 5 Perancangan Input Data Jenis Cuti

\section{Perancangan Form Generate Jadwal Shift Karyawan}

Perancangan ini adalah perancangan yang menampilkan form inpuan parameter untuk jadwal shift Karyawan dengan menggunakan algoritma genetika. Adapun parameter inputan yang diberikan adalah nilai crossover probability, nilai kromosom,nilai mutasi,dan jumlah iterasi. Perancangan ini dapat dilihat pada gambar di bawah ini

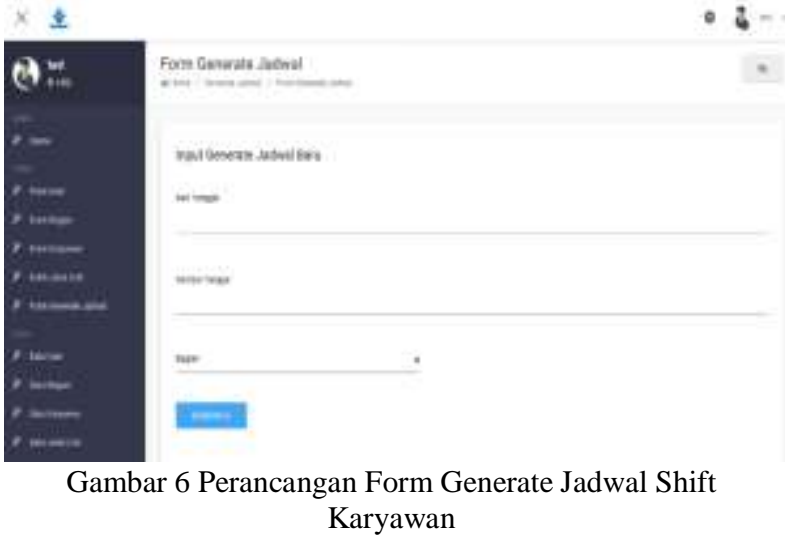

\section{Perancangan Data Hasil Generet Jadwal} Karyawan

Perancangan ini adalah perancangan yang menampilkan data hasil generate jadwal shift Karyawan dengan menggunakan algoritma genetika yang dapat dilihat oleh HRD. Perancangan ini dapat dilihat pada gambar di bawah ini

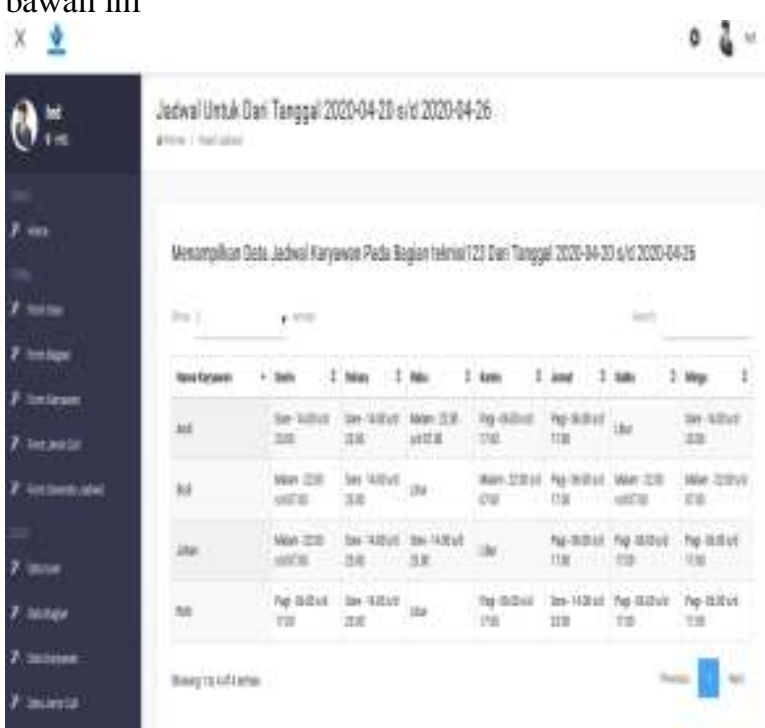

Gambar 7 Perancangan Data Hasil Generate Jadwal Karyawan

\section{Perancangan Data Pengajuan Cuti}

Perancangan data pengajuan cuti adalah perancangan yang menampilkan data pengajuan cuti yang sudah diisi oleh karyawan dan siap untuk dikonfirmasi oleh HRD. Perancangan ini dapat dilihat pada gambar di bawah ini.

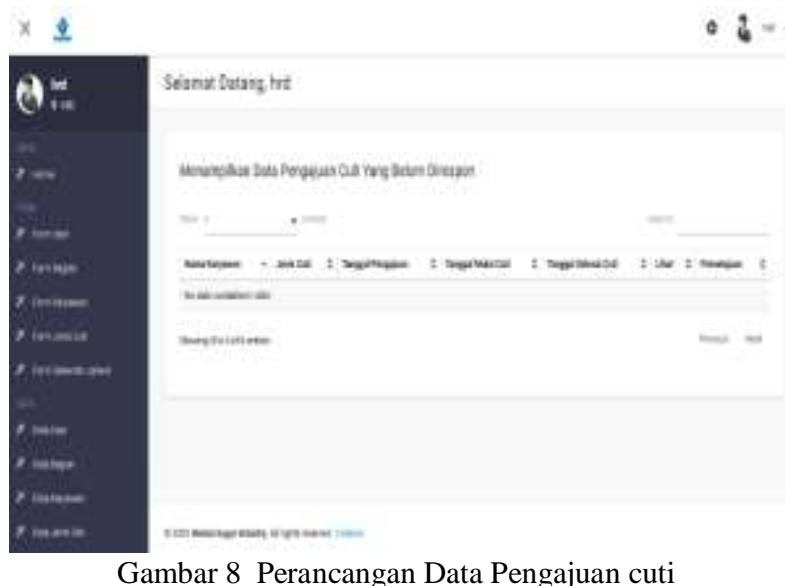




\section{KESIMPULAN}

Berdasarkan Hasil pengujian dan pembahasan yang telah dibuat maka dapat ditarik kesimpulan sebagai berikut :

1. Dengan menggunakan algoritma genetika pada penjadwal dan pengajuan cuti pegawai memberi hasil yang lebih cepat, lebih tepat, dan lebih akurat dan juga lebih sederhana khususnya ketika diterapkan di PT. Medan Sugar Industri.

2. Dengan implementasi algoritma genetika ini maka pekerjaan HRD lebih mudah dan lebih efisien dalam menentukan jadwal shift pegawan

3. Pencarian pegawai sebagai pengganti bagi pegawai yang tidak bisa hadir pada hari tertentu menjadi akan lebih mudah karena HRD bisa melihat langsung pegawai lain yang bisa menggantikan pegawai tersebut.

4. Dengan dibuatnya aplikasi ini diharapkan dapat membantu karyawan dalam mengajukan cuti sehingga dalam meminta perizinan atasan tidak terhambat waktu dan ruang juga membantu staf HRD dalam mengelola laporan pengajuan cuti yang dibuat dalam periode satu tahun.

\section{DAFTAR PUSTAKA}

[1] Abner Mahendra,2015. Rancang Bangun Aplikasi Pelayanan Administrasi Perawatan Sepeda Motor di PT. Surapita Unitrans Surabaya SIKA Vol.4,No. 2. September 2015

[2] Arista Mahaseptiviana, 2014.Analisi dan Perancangan Sistem Informasi Penjualan Air Minum Pada CV. Air Putih

[3]. Chrisantus Tristianto, 2018 Rancang Bangun Media Pembelajaran Berbasis Animasi Pada Materi Instalasi Jaringan Komputer

[4] Indra Griha Tofik Isa, , 2017. Perancangan Aplikasi Koperasi Simpan Pinjam Berbasis Web (Studi Kasus Koperasi Mitra Setia)

[5] Nunung Indra Lesmana, 2016. Penjadwalan Produksi Untuk Meminimalkan Waktu Produksi Dengan Menggunakan Metode Branch and bound (Studi Kasus PT.Malindo Intitama Raya)

[6] Rulia Puji Hastanti,2015. Penjualan Berbasis Web (E-Commerce) Pada Distro Tata Kabupaten Pacitan 